\title{
PENINGKATAN KOMPETENSI GURU DALAM MENULIS LAPORAN PENELITIAN TINDAKAN KELAS (PTK) BERBENTUK ARTIKEL JURNAL MELALUI PENDAMPINGAN DI MTSN 6 TULUNGAGUNG
}

\author{
Maryono \\ Institut Agama Islam Negeri (IAIN) Tulungagung \\ e-mail: mario_stain@yahoo.com
}

\begin{abstract}
Conducting research activities is one of the competencies that should be owned by a profesional teacher, this is because one of the characteristics of an effective teacher is a teacher who has a reflective nature. Classroom action research (CAR) is now one of the efforts to solve problems and improve the quality of learning that can be done by teachers in their classrooms. In the implementation of the service, the service division divides the activity method into three stages which include the planning stage, the organizing stage, the workshop implementation stage, and the evaluation phase. The mentoring participants consisted of 14 teachers from various subject areas at MTs Negeri 6 Tulungagung. Implementation of assistance to better understand the concepts and applications of classroom action research (CAR) is carried out by lecturing, discussion and question and answer methods. The enthusiasm of the participants in asking questions was very good, it was proven that there were more than half of the participants asking questions related to CAR. While the implementation of mentoring to write a class action research report (CAR) in the form of scientific journal articles begins with a workshop on writing narrative learning in class as a form of CAR analysis, online search tracing and reference downloads, and concludes with a workshop on journal article writing based on CAR activities participants have ever carried out. The output (results) achieved in this mentoring are 4 articles about CAR from 4 scientific fields (religion, language, social, and mathematics) submitted in an online journal.
\end{abstract}

Keywords: teacher competency improvement, writing CAR reports, journal articles, mentoring.

\section{PENDAHULUAN}

Melakukan kegiatan penelitian merupakan salah satu kompetensi yang hendaknya dimiliki oleh seorang guru yang profesional, hal ini disebabkan salah satu karakteristik guru yang efektif adalah guru yang mempunyai sifat reflektif. Menurut Hakim (2015) kompetensi yang harus dimiliki oleh guru meliputi kompetensi pedagogik, profesional, sosial dan personal. Guru sebagaimana kriteria tersebut senantiasa belajar dari pengalamannya, oleh karena itu kinerjanya semakin meningkat dari waktu ke waktu. Akan tetapi kenyataannya, kegiatan penelitian ini jarang dilakukan oleh guru. Berbagai alasan disampaikan di antaranya, kurang memiliki pengetahuan dan kemampuan dalam penelitian, kurang pengalaman, waktu yang terbatas karena penelitian biasanya harus meninggalkan kewajiban mengajar, anggapan bahwa penelitian selalu memerlukan biaya yang besar, dan lain sebagainya. Hal-hal tersebut rupanya menjadi perhatian dari para pakar, sehingga akhirnya diformulasikanlah penelitian yang sesuai dengan karakteristik guru yakni Penelitian Tindakan Kelas (PTK) atau Classroom Action Research (CAR). PTK saat ini menjadi salah satu upaya penyelesaian masalah dan peningkatan mutu pembelajaran yang bisa dilakukan oleh guru di kelasnya.

Menurut Arikunto (2007) "PTK merupakan paparan gabungan definisi dari tiga kata penelitian, tindakan, dan kelas". Penelitian dapat didefinisikan sebagai "kegiatan mengamati suatu objek, menggunakan aturan metodologi tertentu untuk memperoleh data atau informasi yang bermanfaat bagi peneliti atau orang-orang yang berkepentingan dalam rangka peningkatan kualitas di berbagai bidang". Tindakan adalah "suatu gerak kegiatan yang sengaja dilakukan dengan tujuan tertentu yang dalam pelaksanaannya berbentuk rangkaian periode/siklus kegiatan". Sedangkan kelas adalah 
"sekelompok siswa yang dalam waktu yang sama dan tempat yang sama menerima pelajaran yang sama dari seorang guru yang sama". Penelitian tindakan kelas yaitu suatu penelitian tindakan yang dilakukan di kelas.

Pendapat lain tentang definisi PTK dikemukakan oleh Kemmis dan Mc Taggart (1998) yang menyebutkan bahwa "PTK adalah suatu bentuk refleksi diri kolektif yang dilakukan oleh pelakunya (peneliti) dalam situasi social untuk meningkatkan penalaran dan praktik social". Sedangkan Carr dan Kemmis menyatakan bahwa "PTK merupakan suatu bentuk refleksi diri yang dilakukan oleh parapartisipan (guru, siswa, atau kepala sekolah) dalam situasi sosial (termasuk pendidikan) untuk memperbaiki rasionalitas dan kebenaran dari: (a) praktik-praktik social atau pendidikan yang dilakukan sendiri, (b) pengertian mengenai praktik-praktik tersebut, (c) situasi-situasi (lembaga-lembaga) tempat praktik-praktik tersebut dilaksanakan".

Karya tulis ilmiah adalah sebuah karya tulis yang disajikan secara ilmiah dalam sebuah forum atau media ilmiah. Karakteristik keilmiahan sebuah karya terdapat pada isi, penyajian, dan bahasa yang digunakan. (Djuroto, 2014:117). Menurut Rif'an (2012:94) Sebuah karya tulis yang baik tentu yang komunikatif, maksudnya pesan yang disampaikan dipahami pembaca sebagaimana maksud penulis. Tulisan yang komunikatif disampaikan melalui bahasa-bahasa yang tersusun sistematis, mudah dicerna, tidak bertele-tele, dan tidak bermakna ganda (ambigu). Tatang (2006: 1) menyebutkan sifat-sifat khas karya tulis ilmiah yang membedakannya dari karya tulis karya tulis non ilmiah yaitu: (1) karangan atau tulisan, (2) dalam bidang ilmu tertentu, (3) berlandaskan fakta-fakta obyektif dan atau hasil penalaran logis, (4) berupa hasil penelitian, kajian literatur, dan atau pemikiran, (5) disusun secara sistematis, (6) dalam ragam karangan ilmiah atau ilmiah populer, (7) disajikan dengan bahasa yang baik dan benar.

Artikel atau article dalam kamus Oxford Inggris-Inggris adalah a piece of writing, usually dealing with a particular issue or topik in a newspaper, magazine, etc. Artikel menunjuk pada tulisan ilmiah tentang suatu isu atau permasalahan yang dipublikasikan pada suatu jurnal, majalah ilmiah, atau surat kabar, dan lain-lain yang sejenis, sedangkan makalah menunjuk pada tulisan ilmiah yang membahas tentang topik bahasan tertentu yang dipublikasikan dalam suatu forum ilmiah seperti seminar, lokakarya, diskusi ilmiah, dan lain-lain. Dengan demikian, perbedaan keduanya dapat dilihat dari media komunikasi atau publikasi yang digunakan, yang sedikit banyak berimplikasi pada sistematika dan isi tulisan.

Artikel dapat berupa artikel hasil penelitian, lazim disebut artikel ilmiah, artikel konseptual, dan artikel populer. Maryadi dalam Harun, dkk (2001: 19) mengatakan bahwa "artikel illmiah adalah naskah yang sering dimuat dalam jurnal-jurnal penelitian. Isinya hampir sama dengan laporan penelitian tapi dibuat mini".

Untuk meningkatkan kualitas pembelajaran secara khusus dan pendidikan secara umum, terutama pada tingkat MTs di Kabupaten Tulungagung sebenarnya sudah dilakukan berbagai program peningkatan kualitas guru di antaranya melalui sosialisasi kurikulum, workshop penyusunan perangkat pembelajaran, pendampingan modelmodel pembelajaran mutakhir, pendampingan penyusunan soal, workshop media dan alat peraga, serta pendampingan di bidang penilaian pembelajaran dan rencana tindak lanjut dari pendampingan penelitian yang telah dilakukan.

Di antara bentuk penelitian yang lain, PTK dianggap sebagai bentuk riset/penelitian yang paling tepat kaitannya dengan peningkatan kualitas pembelajaran. Hal ini dikarenakan pada saat melaksanakan PTK selain sebagai researcher (peneliti) guru juga 
berperan sebagai pelaksana proses pembelajaran, oleh karena itu diharapkan bisa memahami dengan baik masalah yang sedang dihadapi serta perbaikan yang diharapkan. Namun demikian antusiasme guru dalam melaksanakan PTK masih perlu ditingkatkan. Hal ini disebabkan oleh terbatasnya kemampuan dan pengalaman dalam bidang penelitian.

Di samping itu hasil-hasil pelaksanaan PTK kurang menggambarkan tujuan PTK itu sendiri, sebagian besar hasil penelitian tindakan kelas masih rancu dengan penelitian jenis lain khususnya yang menggunakan analisis statistik. Sehingga, perlu upaya untuk meningkatkan pemahaman dan kemampuan guru MTs dalam melaksanakan PTK supaya usaha yang telah dilakukan Kementerian Agama Kab. Tulungagung dapat dioptimalkan. Selain itu sebagian besar guru belum memiliki pengalaman menuliskan karya ilmiah, terutama artikel hasil penelitan tindakan kelas. Oleh karena itu dalam pendampingan ini juga difokuskan pada penulisan artikel dari hasil penelitian tindakan kelas yang selanjutnya akan disubmit ke jurnal ilmiah online.

\section{METODE}

Dalam pelaksanaan pengabdian, pengabdi membagi metode kegiatan ke dalam tiga tahapan yang meliputi tahap perencanaan, tahap pengorganisasian, tahap pelaksanaan pendampingan.

Pada tahap perencanaan kegiatan yang akan dilakukan adalah mengidentifikasi kebutuhan belajar yang hasilnya berupa materi dalam bentuk pengetahuan, meliputi: (1) pemahaman karakteristik peserta workshop, (2) penguasaan konsep tata tulis dan sistematika karya ilmiah, (3) pemahaman perencanaan workshop, (4) pelaksanaan workshop beserta metode dan teknik, dan (5) evaluasi dalam workshop,. Kebutuhan materi dalam bentuk keterampilan, meliputi: (1) penyusunan program workshop, dan jadwal workshop, (2) penyusunan persiapan pelaksanaan workshop, (3) pelaksanaan workshop, dan (4) evaluasi workshop.

Tahap pengorganisasian dalam pengabdian ini meliputi beberapa kegiatan seperti (1) mengenalkan tentang karya ilmiah kepada guru, (2) meningkatkan keefektifan penulisan karya ilmiah sebagai sarana pembelajaran pada guru, (3) menyusun kerangka penulisan karya ilmiah, (4) melaksanakan workshop, (5) melaksanakan evaluasi pendampingan.

Pengkondisian awal sebelum workshop inti dimulai meliputi kegiatan (1) menciptakan suasana yang kondusif untuk mengikuti workshop, (2) memberikan pemahaman terhadap langkah-langkah kegiatan yang harus ditempuh selama workshop, (3) menyampaikan kebermanfaatan mengikuti kegiatan workshop, (4) menginformasikan berbagai kegiatan dalam pelaksanaan workshop secara keseluruhan yang harus dilakukan peserta workshop meliputi kegiatan teori dan praktik.

Proses workshop pada dasarnya dibedakan menjadi tiga kegiatan yaitu kegiatan pendahuluan, kegiatan inti, dan kegiatan penutup. Pertama, pada kegiatan pendahuluan (1) pengabdi membangun perhatian peserta, (2) pengabdi berupaya memotivasi peserta dengan cara menciptakan suasana akrab, menyapa dan berkomunikasi dengan peserta secara kekeluargaan, dan (3) pengabdi memberikan panduan dalam menyusun/menulis karya ilmiah yang akan dilakukan. Kedua, pada kegiatan inti fasilitator akan memberikan pendampingan mengenai menulis karya ilmiah meliputi (1) persiapan sarana dan prasarana, (2) pengetahuan tentang karya ilmiah, (3) kaidah tata tulis karya ilmiah, (4) sistematika penulisan karya ilmiah, dan (5) praktik penyusunan karya ilmiah. Ketiga, pada kegiatan penutup pengabdi akan mengajak peserta untuk merefleksi kembali dan menyimpulkan kegiatan workshop 
Evaluasi kegiatan ini akan dilakukan secara langsung dan tidak langsung. Evaluasi secara langsung dilakukan pada saat workshop yang mencakup: (1) bagaimana keseriusan guru dalam mengikuti kegiatan workshop ini, (2) bagaimana pengetahuan guru tentang hakikat penelitian, (3) bagaimana pengetahuan guru tentang hakikat artikel ilmiah dan kaidah selingkungnya, serta (4) kemampuan guru mempraktikkan menyusun artikel ilmiah. Kemudian, evaluasi secara tidak langsung berupa pemantauan tindak lanjut kegiatan ini, yaitu: (1) bagaimana para guru menerapkan pengetahuan yang telah diperolehnya dalam pendampingan dan (2) bagaimana para guru menindaklanjuti kegiatan workshop ini untuk membuat artikel ilmiah sesuai dengan bidangnya. Adapun instrumen yang digunakan dalam evaluasi pendampingan ini adalah lembar observasi dan catatan lapangan.

\section{HASIL KARYA UTAMA DAN PEMBAHASAN}

Pelaksanaan program pendampingan ini secara umum dapat dibagi menjadi 4 (empat) tahapan, yaitu: (1) tahap persiapan, (2) tahap sosialisasi, (3) tahap pelaksanaan, dan (4) tahap pelaporan.

\section{Tahap Persiapan}

Tahap ini diawali dengan melakukan studi pendahuluan dengan cara observasi awal ke lokasi pendampingan dan melakukan wawancara awal dengan beberapa tenaga pendidik. Hasilnya sebagaimana paparan pada subbab A. Kondisi lokasi pendampingan yang sudah dideskripsikan sebelumnya. Selain itu pada tahap ini juga dilakukan silaturahmi sekaligus komunikasi awal dengan Kepala Madrasah serta ijin secara lisan terkait rencana pendampingan yang akan dilaksanakan di MTsN 6 Tulungagung. Secara umum Kepala Madrasah sangat mendukung kegiatan ini, dikarenakan kegiatan pendampingan ini benar-benar akan dirasakan manfaatnya oleh para peserta.

Setelah komunikasi awal dengan pihak sekolah dilaksanakan, selanjutnya dilaksanakan pengurusan perizinan secara formal ke LP2M yang ditujukan kepada MTsN 6 Tulungagung sebagai madrasah yang menjadi lokasi pendampingan. Selain itu juga disusun perencanaan kegiatan serta pemateri/fasilitator yang akan dilibatkan dalam kegiatan ini. Pelaksanaan kegiatan dibagi dalam 2 sesi, yaitu: sesi materi dan sesi workshop. Untuk kedua sesi tersebut pelaksana kegiatan merencanakan pemateri sebagai berikut: (1) sesi materi: Dr. Muniri, M.Pd. (Materi Karya Tulis Ilmiah dengan durasi 1 pertemuan) dan Dr. Ummu Sholihah, M.Si. (Materi PTK durasi 1 pertemuan); (2) sesi workshop: Dr Dewi Asmarani, M.Pd. (Workshop pencarian sumber referensi dari internet durasi 1 pertemuan) dan Beni Asyhar, S.Si., M.Pd. (Workshop Penyusunan Laporan PTK dalam bentuk artikel dan cara melakukan submit artikel ke jurnal online, serta praktik uji similarity menggunakan aplikasi turnitin durasi 2 pertemuan).

Namun dari keempat pemateri yang sudah dikonfirmasi, hanya 2 yang siap untuk terlibat dalam kegiatan ini, yaitu Dr. Muniri, M.Pd. dan Beni Asyhar, S.Si., M.Pd. Oleh karena itu, rancangan yang sudah dibuat akan mengalami perubahan khususnya pengampu materi/workshop. Dalam hal ini peneliti akan bertindak sebagai fasilitator menggantikan 2 pemateri yang berhalangan tersebut. Pada tahap persiapan ini juga dilakukan penggandaan dan penjilidan materi pendampingan sebanyak 20 jilid dengan rincian: 14 jilid untuk peserta, 1 jilid untuk arsip sekolah, 1 jilid untuk pegangan peneliti, 1 jilid untuk pegangan pembantu peneliti, dan 3 jilid untuk pegangan pemateri. 


\section{Tahap Sosialisasi}

Setelah tahap persiapan dirasa cukup, selanjutnya dilaksanakan tahap sosialiasi kepada calon peserta pendampingan. Kegiatan ini dilaksanakan pada hari Sabtu tanggal 7 September 2019 dan bertempat di musholla Madrasah. Calon peserta pendampingan terdiri dari berbagai guru pengampu bidang studi, yaitu: Akidah Akhlak, Fiqih, Bahasa Indonesia, Bahasa Inggris, IPA, dan Matematika. Adapun jumlah calon peserta yang yang hadir sebanyak 9 guru dari 15 guru yang diundang.

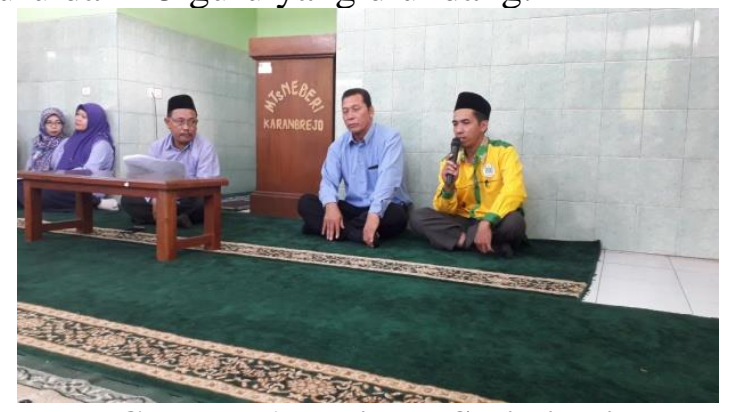

Gambar 1 Kegiatan Sosialisasi

Pada kegiatan ini disampaikan rencana pelaksanaan kegiatan pendampingan sebagaimana sudah dideskripsikan pada tahap sebelumnya. Selain itu supaya pelaksanaan pendampingan ini tidak mengganggu kegiatan belajar mengajar, maka disepakati bahwa pendampingan ini akan dilaksanakan setiap hari minggu, selama 5 kali pertemuan dengan masing-masing pertemuan 4 jam (mulai pukul $08.00 \mathrm{sd} 12.00$ ). Tempat pendampingan akan dilaksanakan di laboratorium komputer, mengingat kegiatan ini akan banyak praktik yang membutuhkan komputer dan jaringan internet. Selain itu juga disepakati bahwa kegiatan pendampingan akan dimulai pada tanggal 15 September 2019.

\section{Tahap Pelaksanaan}

Pertemuan ke-1 (Minggu, 15 September 2019)

Sesuai kesepakatan dengan peserta pendampingan, bahwa pertemuan pertama dilaksanakan pada hari Minggu, tanggal 15 September 2019 mulai pukul 08.00 WIB sampai dengan 12.00 WIB bertempat di laboratorium komputer Madrasah. Pertemuan pertama ini dihadiri 14 peserta, dengan pemateri/narasumber adalah Bapak Dr. Muniri, M.Pd. (Pakar Pendidikan sekaligus Wakil Dekan bidang kemahasiswaan dan kerjasama Fakultas Tarbiyah dan Ilmu Keguruan IAIN Tulungagung). Adapun materi yang disampaikan pada pertemuan ini adalah tentang Karya Tulis Ilmiah dalam dunia pendidikan.

Pada pertemuan pertama ini peserta pendampingan terlihat begitu antusias, hal ini terlihat dari kedatangan mereka yang rata-rata sebelum pukul 07.50 sudah sampai lokasi kegiatan, sehingga tepat pukul 08.05 WIB kegiatan perdana ini bisa dimulai. Kegiatan hari itu diawali dengan pengantar dari ketua pendampingan (Bapak Dr. Maryono) sekaligus mengenalkan pemateri pada hari itu kepada peserta. Pada pengantar tersebut ketua pendampingan menyampaikan terima kasih atas kesediaan peserta dan pemateri untuk hadir pada pertemuan hari itu. Disampaikan juga bahwa kegiatan ini akan dilaksanakan sebanyak 5 (lima) kali pertemuan setiap hari Minggu. 


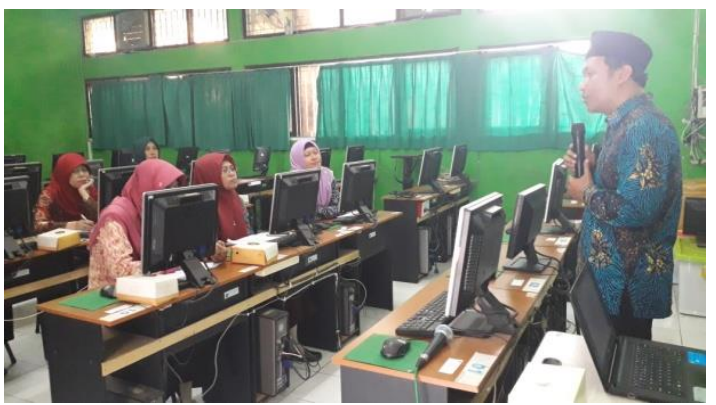

Gambar 2 Kegiatan pada pertemuan ke-1

Setelah pemberian pengantar, kegiatan dilanjutkan dengan pemaparan materi oleh Bapak Muniri tentang Karya Tulis Ilmiah dalam pendidikan. Metode yang digunakan pada sesi hari ini adalah ceramah dan tanya-jawab. Pada pemaparan awal, pemateri juga menyinggung bagaimana peranan karya tulis ilmiah kaitannya dengan peningkatan profesionalisme guru.

Setelah sesi pemaparan materi selesai, selanjutnya dibuka sesi tanya jawab. Nampak peserta sangat antusias untuk merespons materi dengan memberikan pertanyaan. Dari 14 peserta yang hadir, 7 di antaranya meyampaikan pertanyaan. Di antara pertanyaan yang disampaikan peserta adalah tentang bagaimana kiat-kiat supaya guru memiliki motivasi untuk lebih gemar menulis karya ilmiah? Bagaimana perkembangan model-model pembelajaran saat ini? Bagaimana meningkatkan kompetensi guru bidang profesional (penguasaan konten)? Selain pertanyaan, beberapa peserta juga memberikan saran atau masukan kepada pihak kampus IAIN Tulungagung, yaitu: mereka menyarankan alangkah baiknya untuk merefresh situasi pembelajaran di MTsN 6 Tulungagung, ada beberapa dosen yang berkenan untuk menjadi guru model, supaya bisa menjadi inspirasi guru-guru yang ada di sana.

Beberapa pertanyaan tersebut langsung dijawab/direspons oleh pemateri. Secara umum pemateri menyampaikan bahwa untuk meningkatkan motivasi guru dalam menulis karya ilmiah bisa dilakukan kegiatan, di antaranya adalah: workshop kepenulisan karya ilmiah, melakukan kolaborasi penelitian dengan guru sekolah lain atau dengan dosen, serta sering mengikuti kegiatan-kegiatan ilmiah seperti seminar, lokakarya, pendampingan atau sejenisnya. Adapun untuk model-model terbaru pemateri menyampaikan sebaiknya mengikuti rekomendasi kurikulum 2013 yaitu bisa memilih di antara 3 model/pendekatan: saintifik, problem based learning, atau project based learning. Sedangkan untuk meningkatkan kompetensi profesional (konten) sebaiknya kegiatan MGMP atau KKG dioptimalkan dan disisipi diskusi mengenai materi/konten masing-masing bidang studi. Selain itu juga bisa dilakukan dengan mengundang pakar dari perguruan tinggi untuk meng-update pengetahuan konten. Adapun untuk usulan tentang guru model dari unsur dosen akan dipertimbangkan dan akan dibahas lebih lanjut di tingkat Fakultas melalui pusat studi Red-C milik FTIK IAIN Tulungagung.

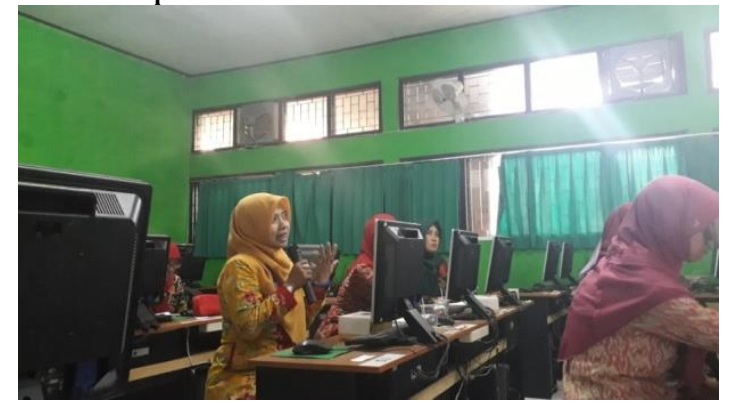

Gambar 3 Salah satu peserta mengajukan pertanyaan pada pertemuan ke-1 
Setelah semua pertanyaan dan masukan mendapatkan jawaban/respons dari pemateri, selanjutnya ketua tim pendampingan (yang pada pertemuan pertama ini sekaligus bertindak sebagai pemandu/moderator) menyimpulkan hasil diskusi pada hari itu. Selain itu ketua tim juga menyampaikan bahwa materi minggu depan adalah Penelitian Tindakan Kelas, dan jika tidak ada halangan pemateri yang akan hadir adalah Ibu Dr. Ummu Sholihah, M.Si, selaku ketua jurusan Tadris Matematika. Selanjutnya ketua tim menutup kegiatan pada hari itu dengan mengucapkan salam penutup.

\section{Pertemuan ke-2 (Minggu, 22 September 2019)}

Pemateri untuk sesi materi ini sesuai perencanaan adalah Ibu Dr. Ummu Sholihah, M.Si. Namun karena sesuatu dan lain hal beliau berhalangan hadir sehingga ketua tim pendampingan sendiri yang menyampaikan materi ini dengan dibantu pembantu/asisten pendampingan yaitu Saudari Windy Ariyanti (mahasiswa semester 7 jurusan Tadris Matematika). Peserta yang hadir pada pertemuan kedua ini sebanyak 14 guru. Pada pertemuan ini materi yang disampaikan adalah tentang penelitian tindakan kelas, mulai penjelasan definisi PTK, langkah-langkah PTK sampai dengan cara penulisan laporan PTK. Karena secara umum guru sudah mengenal PTK, maka pemaparan materi pada hari itu lebih banyak dialog/diskusi seputar PTK.

Ada beberapa pertanyaan yang disampaikan peserta di antaranya adalah: Apa sebenarnya pendekatan dari PTK? PTK itu minimal berapa siklus dan maksimal berapa siklus? Apakah dari siklus 1 ke siklus selanjutnya materi boleh tetap? Mengapa dalam PTK harus melibatkan orang lain sebagai kolaborator? Apa perbedaan PTK dengan penelitian eksperimen? Bagaimana menentukan kriteria keberhasilan suatu siklus? Bagaimana memilih "penyakit" yang terjadi di kelas untuk "disembuhkan" melalui PTK jika penyakitnya banyak? Pertanyaan-pertanyaan tersebut selanjutnya dijawab oleh pemateri dan diuraikan sebagaimana deskripsi selanjutnya.

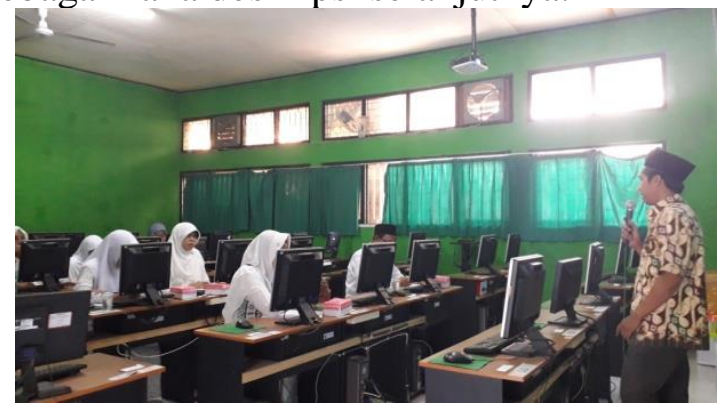

Gambar 4 Kegiatan pada pertemuan ke-2

Untuk pertanyaan pertama yaitu mengenai pendekatan PTK, pemateri menyampaikan bahwa ada beberapa pendapat ahli mengenai pendekatan dari PTK. Pertama, PTK merupakan jenis penelitian yang menggunakan pendekatan kualitatif, karena PTK lebih menekankan proses daripada hasil, sehingga analisis datanya menggunakan analisis deskriptif, bukan analisis statistik. Kedua, PTK merupakan jenis penelitian yang mandiri, bukan kualitatif, juga bukan kuantitatif. Dari beberapa pendapat tersebut pemateri menyampaikan pendapat yang paling banyak digunakan adalah pendapat yang pertama, karena karakteristik PTK lebih cocok dengan karakteristik kualitatif. Adapun analisis yang melibatkan angka-angka (kuantitatif) hanyalah untuk melengkapi analisis yang deskriptif.

Adapun untuk pertanyaan yang kedua, pemateri menyampaikan sebenarnya tidak ada batasan minimal dan maksimal dari siklus PTK. Namun demikian, sebagai ramburambu untuk acuan pelaksanaan biasanya digunakan kesepakatan tidak tertulis bahwa 
batas minimal PTK adalah 3 siklus dan maksimal 5 siklus. Artinya, walaupun pada siklus 1 sudah menunjukkan hasil yang baik, tetapi sebaiknya dilanjutkan ke siklus 2 supaya polanya lebih terlihat. Adapun jika sampai 5 siklus PTK tidak mampu meningkatkan hasil, maka sebaiknya PTK dihentikan untuk dievaluasi dan ditinjau kembali.

Sedangkan terkait materi, dalam PTK tidak boleh mengulang materi yang sama persis pada siklus yang berbeda. Hal ini bisa didasarkan pada logika sederhana, bahwa jika materi pada 2 siklus berbeda tetap, maka peningkatan hasil akan sulit untuk disimpulkan apakah karena treatment yang diberikan atau karena pengulangan materi. Perbedaan materi yang dimaksud bukan berarti berganti bab, tetapi berganti KD pada materi yang sama, bukan mengulang KD yang sama.

Selanjutnya untuk menjawab pertanyaan perlunya kolaborator dalam PTK, pemateri menyampaikan bahwa dalam PTK teman sejawat/kolaborator mutlak diperlukan. Alasannya, karena dalam PTK ada langkah observasi yang mau tidak mau pasti melibatkan orang lain. Selain itu kolaborator juga diperlukan ketika guru yang melakukan PTK sampai pada tahap refleksi, yaitu untuk menentukan perbaikan pada siklus berikutnya, maka diperlukan teman sejawat untuk berdiskusi, supaya perbaikan yang dilakukan bisa maksimal.

Terkait dengan perbedaan PTK dengan penelitian eksperimen, pemateri menyampaikan bahwa PTK memang ada kemiripan dengan penelitian eksperimen, yaitu sama-sama menerapkan suatu treatmen untuk meningkatkan kualitas atau hasil pembelajaran. Tetapi yang membedakan adalah pada oientasinya, pada PTK mengorientasikan proses pelaksanaan treatmen, sedangkan pada penelitian eksperimen mengorientasikan hasil dari pelaksanaan treatmen. Selain itu dalam PTK dikenal siklus, dalam penelitian eksperimen tidak dikenal siklus. Analisis PTK cenderung kualitatif, sedangkan analisis penelitian eksperimen adalah kuantitatif.

Untuk menentukan kriteria keberhasilan tindakan tiap siklus, secara umum dibagi menjadi kriteria keberhasilan proses dan kriteria keberhasilan hasil tindakan. Untuk kriteria keberhasilan proses, bisa menggunakan analisis hasil observasi. Sedangkan kriteria keberhasilan hasil tindakan bisa menggunakan hasil tes, angket, dan sebagainya. Adapun tindakan dikatakan berhasil atau belum ditentukan dengan kriteria tertentu baik secara kuantitatif maupun secara kualitatif. Jika pada suatu siklus indikator keberhasilan sudah dipenuhi, maka peneliti (guru) diperkenankan untuk berhenti atau melanjutkan 1 siklus lagi (supaya lebih memantabkan hasil).

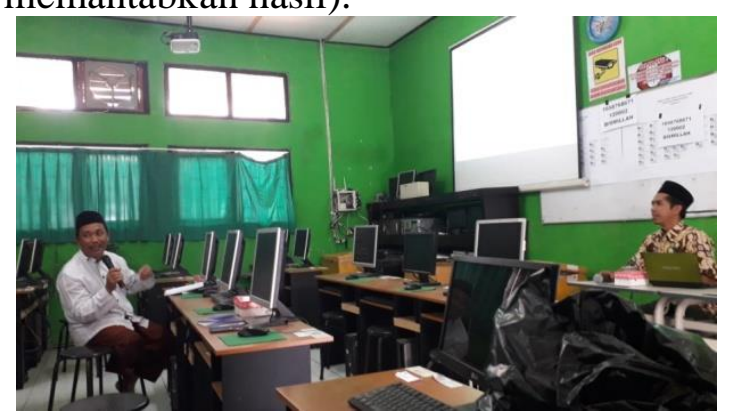

Gambar 5 Salah satu peserta mengajukan pertanyaan pada pertemuan ke-2

Adapun untuk menentukan "penyakit" apa yang harus segera diatasi melalui PTK, maka digunakan skala prioritas. Artinya, di antara permasalahan yang ada, mana yang sifatnya paling krusial dan kritis serta harus segera diatasi, karena PTK tidak bisa menyelesaikan banyak masalah dalam 1 periode pelaksanaannya. Visi dan misi sekolah juga bisa digunakan sebagai bahan pertimbangan dalam memilih prioritas yang harus 
didahulukan. Demikian juga sarana dan prasarana, ketersediaan dan kemampuan SDM, ketersediaan alat dan bahan sangat mempengaruhi prioritas mana yang dipilih.

Pada akhir sesi tim pelaksana menyampaikan bahwa tugas untuk pertemuan selanjutnya adalah membuat narasi (deskripsi) proses pembelajaran yang dilaksanakan dengan metode/model/pendekatan tertentu dengan durasi 30 menit pertama. Selain itu target tugas akhir adalah menyusun laporan PTK, dan dikarenakan waktu pendampingan/ pendampingan yang relatif singkat, maka tim pelaksana menyampaikan bahwa tagihan untuk kegiatan ini adalah laporan dalam bentuk artikel ilmiah.

\section{Pertemuan ke-3 (Minggu, 29 September 2019)}

Pada pertemuan ini, bertindak sebagai fasilitator (pemateri) adalah Bapak Beni Asyhar, S.Si., M.Pd. materi yang disampaikan adalah cara mencari dan mengunduh sumber pustaka secara online, khususnya jurnal online. Materi ini dirasa penting karena banyak peserta yang kesulitan untuk mengakses referensi atau sumber pustaka secara online, yang sebenarnya jumlahnya sangat berlimpah di dunia maya. Hal ini juga ditunjang dengan kekurangpahaman sebagian besar peserta bahwa saat ini terjadi pergeseran paradigma penggunaan pustaka, jika zaman dulu lebih banyak referensi buku untuk karya ilmiah, sekarang diutamakan jurnal ilmiah (bahkan ada yang mengatakan untuk jurnal ilmiah adalah minimal $70 \%$ dari total referensi).

Beberapa laman/portal yang direkomendasikan oleh fasilitator untuk melakukan pencarian referensi online adalah: garuda, sinta, googlescholar, moraref, crossref, dan DOAJ. Walaupun demikian pemateri juga menyampaikan masih banyak laman-laman yang bisa diakses selain yang sudah disebutkan di atas.

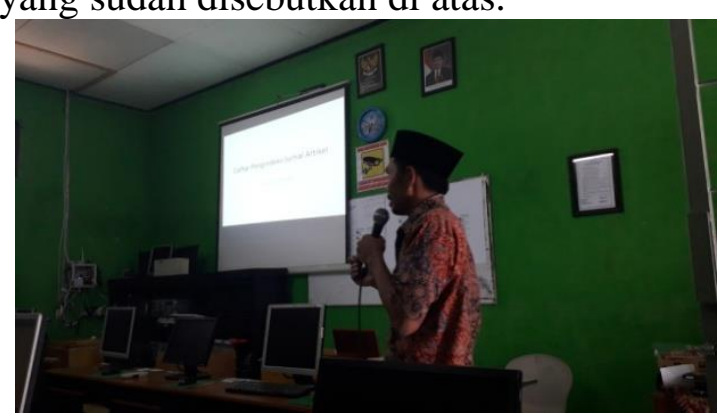

Gambar 6 Kegiatan pada pertemuan ke-3

Pada praktik yang awal, pemateri meminta peserta untuk membuka portal moraref (kepunyaan Kemenag). Dengan bimbingan pemateri dan dibantu ketua tim pengabdian, peserta bisa masuk ke portal moraref dengan cukup mudah. Selanjutnya peserta diminta untuk memasukkan kata kunci untuk menelusuri artikel yang dikehendaki. Karena workshop ini orientasinya pada PTK, maka disarankan untuk mencoba menelusuri model-model atau pendekatan pembelajaran yang cukup kontemporer. Hasilnya peserta bisa melakukan proses download sendiri dan selanjutnya disimpan dalam memori komputer.

Proses ini berlanjut dengan mencoba portal yang lain, yaitu garuda, googlescholar, dan DOAJ. Dengan cara yang sama peserta dibimbing untuk mencari referensi-referensi online khususnya berupa artikel jurnal. Selama kegiatan ini peserta nampak sangat antusias, karena bagi sebagian besar mereka, ini merupakan ilmu dan pengalaman baru. Karena yang selama ini mereka ketahui untuk mencari segala sesuatu termasuk artikel, hanya melalui google atau yahoo. 


\section{Pertemuan ke-4 (Minggu, 6 Oktober 2019)}

Pada pertemuan ini seharusnya yang menjadi fasilitator adalah Ibu Dr. Dewi Asmarani, M.Pd., namun pada hari ini beliau tidak bisa hadir sehingga tim pelaksana sendiri yang mengisi kegiatan pada hari ini. Workshop pada hari ini adalah tentang cara mendeskripsikan/menarasikan kegiatan pembelajaran. Kegiatan ini dirasa sangat perlu karena dalam PTK analisis yang digunakan adalah analisis kualitatif yang bersifat deskriptif (tentang bagaimana proses pembelajaran) dan analisis statistik sederhana.

Kegiatan diawali dengan penyampaian sekilas materi tentang analisis data pada penelitian tindakan kelas (PTK). Bahwasanya dalam PTK analisis yang digunakan adalah analisis data kualitatif. Dalam analisis kualitatif, tidak digunakan rumus-rumus statistik, tetapi menggunakan analisis yang bersifat deskriptif. Oleh karena itu dalam PTK diperlukan kemampuan mendeskripsikan dan menarasikan semua data yang diperoleh setelah melalui proses reduksi data (memilah-milah data yang digunakan dan tidak digunakan).

Selanjutnya juga disampaikan bahwa dalam mendeskripsikan atau menarasikan data kualitatif, sebaiknya mengalir saja mengikuti alur yang ada. Artinya peneliti tidak perlu terbebani dengan aturan-aturan penulisan yang terlalu kaku/formal. Tetapi tentu kaidah-kaidah dalam menulis paragraf harus tetap diperhatikan, di antaranya kalimat harus memuat paling tidak subjek $(\mathrm{S})$ dan predikat $(\mathrm{O})$, lebih baik lagi dilengkapi dengan objek $(\mathrm{O})$ dan keterangan $(\mathrm{K})$. Selain itu dalam 1 paragraf harus terdapat 1 kalimat pokok dan 1 atau lebih kalimat penjelas. Juga tidak kalah pentingnya adalah koherensi antar paragraf, yaitu antara paragraf satu dengan paragraf lainnya harus ada keterkaitan.

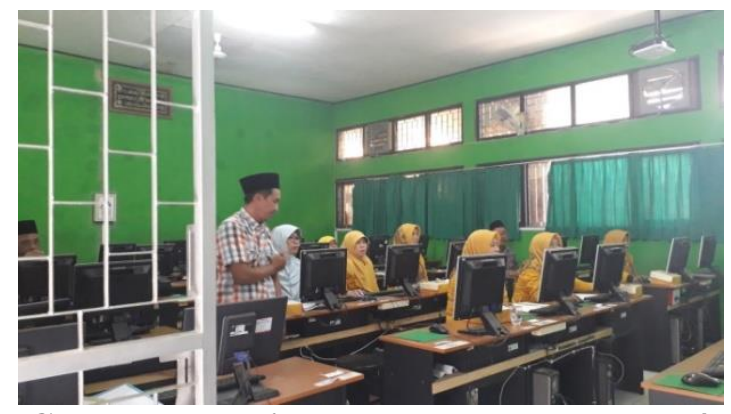

Gambar 7 Kegiatan pada pertemuan ke-4

Selanjutnya peserta diberikan kesempatan untuk menarasikan kegiatan pembelajaran yang terakhir kali dilaksanakan dengan durasi selama 30 menit pertama ke dalam bentuk karangan bebas. Terlihat bahwa pada awal kegiatan ini peserta banyak yang bingung harus memulai dari mana, karena rata-rata mereka belum atau kurang terbiasa melakukan hal ini. Peneliti terus memberikan motivasi dan semangat, bahwa peserta diminta untuk menuliskan saja apa yang dilakukan secara mengalir, jangan terbebani sama sekali misalnya ada yang mengatakan tulisannya kurang bermutu atau lainnya. Dari hasil pengamatan peneliti, sebagian besar peserta memang terlihat sangat canggung pada awal-awal melakukan tugas ini, tapi lambat laun terlihat bahwa mereka mulai bisa menuliskan narasi pembelajaran dengan lebih rileks dan mengalir.

Setelah diberikan kesempatan selama kurang lebih 45 menit untuk menuliskan narasi pembelajaran, selanjutnya secara bergantian peserta diminta untuk mempresentasikan hasil pekerjaannya, untuk dievaluasi bersama-sama. Dari hasil presentasi, didapatkan beberapa tipe hasil pekerjaan peserta. Ada peserta yang sebenarnya mampu menarasikan dengan baik, namun tidak bisa bercerita secara detail, 
yang ditulis hanya bagian-bagian inti saja. Ada juga peserta lain yang menuliskan narasi seperti membuat teks dialog. Ditemukan juga peserta yang sudah menuliskan narasi sesuai yang diharapkan, yaitu menuliskan alur cerita pembelajaran secara runtut dan rinci. Selain itu juga ditemukan sebagian besar peserta dalam menulis mengabaikan kaidah-kaidah menulis kalimat dan paragraf yang tepat.

Kegiatan pada pertemuan hari ini ditutup dengan pemberian tugas menuliskan laporan PTK dalam bentuk artikel, mengacu pada contoh-contoh artikel PTK yang sudah diberikan peneliti ke peserta. Semua peserta pada dasarnya sudah pernah membuat laporan PTK tetapi bukan dalam format artikel. Oleh karena itu penugasan kali ini bertujuan memberikan pengalaman kepada peserta untuk menuliskan laporan dalam format artikel jurnal, sekaligus pada pertemuan selanjutnya mereka akan dibimbing melakukan cek plagiasi dan similarity serta praktik melakukan submit ke jurnal online.

\section{Pertemuan ke-5 (Minggu, 13 Oktober 2019)}

Pemateri/instruktur pada pertemuan ke-5 ini adalah Bapak Beni Asyhar, S.Si., M.Pd dengan materi praktik mengecek similarity karya ilmiah berupa artikel jurnal yang sudah dibuat peserta sekaligus praktik submit artikel ke salah satu OJS sesuai dengan rumpun bidang ilmu peserta. Pada sesi 1 instruktur memberikan penjelasan mengenai pentingnya pengecekan similarity suatu karya ilmiah sebelum disubmit atau dikirim ke jurnal ilmiah online atau akan diikutkan dalam prosiding seminar. Selain itu instruktur juga menyampaikan cara mengecek kesamaan/similarity adalah dengan menggunakan software berbayar yang salah satunya adalah turnitin. Karena berbayar, maka pada kesempatan hari itu untuk mempraktikkan pengecekan similarity, peserta difasilitasi akun turnitin dari instruktur.

Dari 14 peserta, yang karyanya dijadikan sampel untuk diuji similarity sebanyak 7 peserta. Dari 7 artikel tersebut yang tingkat kesamaannya di bawah 35\% hanya satu artikel yaitu artikel dari Ibu Umi Maghfiroh. Sedangkan 6 artikel lainnya, artikel masih berada pada tingkat kesamaan yang tinggi (di atas 50\%). Oleh karena itu untuk sesi selanjutnya, yaitu praktik submit ke OJS, yang langsung bisa disubmit adalah 1 artikel. Sedangkan 6 artikel lainnya harus direvisi dulu supaya turun tingkat kesamaannya. Oleh karena itu pada kesempatan itu instruktur juga memberikan tips-tips supaya similarity bisa turun. Pada sesi berikutnya peserta dibimbing untuk membuat akun OJS yang ada di IAIN Tulungagung sesuai bidang masing-masing. Setelah semua peserta berhasil memiliki akun, selanjutnya untuk artikel kepunyaan Bu Umi langsung dipraktikkan untuk disubmit ke Jurnal Lingua Scientia.

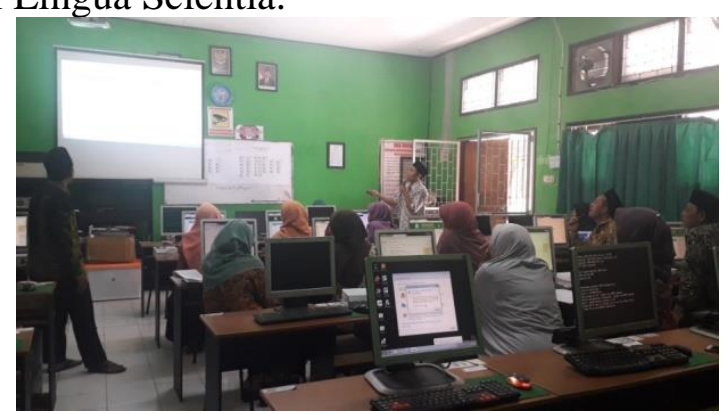

Gambar 8 Kegiatan pada pertemuan ke-5 


\section{Tahap Pelaporan}

Setelah pertemuan ke-5 yang merupakan pertemuan terakhir selesai dilaksanakan, selanjutnya peneliti mengurus surat keterangan selesai melaksanakan pengabdian kepada pihak Madrasah. Selanjutnya peneliti melakukan analisis data sekaligus penulisan laporan kegiatan pengabdian masyarakat ini. Data yang terkumpul berupa: hasil observasi selama kegiatan, hasil/produk peserta selama pendampingan, serta kumpulan pernyataan verbal baik dari proses tanya jawab maupun ketika diskusi sedang berlangsung. Adapun laporan yang harus diselesaikan berupa artikel jurnal hasil pengabdian.

\section{KESIMPULAN}

Pelaksanaan pendampingan untuk lebih memahami konsep dan aplikasi penelitian tindakan kelas (PTK) dilaksanakan dengan metode ceramah, diskusi, dan tanya jawab. Antusiasme peserta dalam mengajukan pertanyaan sangat baik, hal ini terbukti ada lebih dari separuh peserta mengajukan pertanyaan terkait PTK. Sedangkan pelaksanaan pendampingan untuk menuliskan laporan penelitian tindakan kelas (PTK) dalam bentuk artikel jurnal ilmiah diawali dengan workshop penulisan narasi pembelajaran dalam kelas sebagai bentuk analisis PTK, workshop penelusuran dan pengunduhan referensi secara online, dan diakhiri dengan workshop penulisan artikel jurnal berdasarkan kegiatan PTK yang pernah dilaksanakan peserta. Adapun pelaksanaan pendampingan untuk mengirim (submit) artikel jurnal ke jurnal ilmiah online dilakukan dengan mengenalkan open journal system (OJS), praktik cara melakukan register ke salah satu OJS, dan praktik cara submit artikel yang sudah disiapkan ke salah satu OJS. Selain itu peserta juga dikenalkan dengan pengecekan kemiripan karya ilmiah menggunakan aplikasi turnitin.

\section{DAFTAR PUSTAKA}

Arikunto, 2007. Prosedur penelitian suatu pendekatan praktik. Jakarta: Rineka Aksara. Djuroto, Totok. 2014. Menulis artikel karya ilmiah. Bandung: Rosda Karya.

Hakim, Adnan. 2015. "Contribution of Competence Teacher (Pedagogical, Personality, Profesional Competence and Social) on the Performance of Learning". The International Journal of Engineering and Science (IJES). Volume 4 Issue 2 PP.0112 ISSN: 2319 - 1813 ISSN: 2319 - 1805. Diakses pada tanggal 20 Oktober 2019.

Kemmis, s. \& McTaggart, R. 1988. The Action Research Planner. 3rd ed. Victoria, Australia: Deakin University.

Maryadi. 2001. Pengertian dan Kriteria Karya Ilmiah. Dalam Harun, dkk. (Eds.), Pembudayaan Penulisan Karya Ilmiah (hlm. 13-14). Surakarta: Universitas Muhammadiyah Surakarta.

Rif'an, Ali. 2012. Jenius Menulis dan Publikasi Karya Ilmiah. Solo: Kreasi Cerdas.

Tatang, M. Amirin. 2006. Menulis Karya Ilmiah (Artikel). Makalah Pendampingan Penulisan Karya Ilmiah Bagi Guru-guru se-Indonesia. Yogyakarta, 2-3 November. 